\title{
RANCANG BANGUN SISTEM INFORMASI INVENTORI MENGGUNAKAN METODE ASSOCIATION RULES DI CV. DAMAR LANGIT
}

\author{
Zainul Fanani - Muhammad Faisal \\ Jurusan Teknik Informatika \\ Fakultas Sains dan Teknologi \\ Universitas Islam Negeri Maulana Malik Ibrahim Malang. \\ Email: seminull@yahoo.com-muhfais@yahoo.com,
}

\begin{abstract}
Abstrak - Sistem informasi manajemen inventori merupakan sistem informasi yang mengelola data transaksi dan persediaan dalam gudang. Perusahaan yang bergerak dibidang produksi umumnya memerlukan Sistem Inventori. Sistem Inventori biasanya terdiri dari sistem penerimaan barang, sistem pembelian barang, dan sistem gudang. Sistem ini harus dapat memberikan informasi inventori seperti informasi pengeluaran barang, pembelian barang, penerimaan barang dan informasi lain secara cepat dan akurat, selain itu sistem dapat mempermudah kerja user.Pada penelitian yang dilakukan berkaitan dengan rancang bangun sistem informasi inventori menggunakan association rules (aturan asosiasi), bertujuan sebagai sistem pendukung keputusan untuk merekomendasikan persediaan sepeda motor sesuai tipe dan warna dengan menganalisa data penjualan sepeda motor SUZUKI. Dan dari aplikasi ini dapat mengetahui pola/ kebiasaan customer dalam kecenderungan membeli sepeda motor. Sehingga dari aturan asosiasi ini menghasilkan informasi yang bisa digunakan untuk membantu dalam mendukung keputusan seorang manager dalam manajemen perusahaan terutama dalam memecahkan permasalahan yang berhubungan dengan inventori (persediaan) sepeda motor dari produk SUZUKI yang sesuai tipe dan warna dengan tipe dan warna yang lainnya, sehingga dapat bermanfaat dalam menentukan strategi pemasaran. Selanjutnya seorang pimpinan operasional dapat merencanakan sendiri untuk menentukan jumlah pembelian. Dan output dari aplikasi sistem informasi jumlah sisa persediaan didapat dari hasil pemrosesan didalam database.
\end{abstract}

Kata Kunci : Sistem informasi, Inventori, Sistem Pendukung Keputusan (Decisition Support System), Association Rule, Data Mining, OLAP (Online Analitic Processing), Algoritma Apriori, Support, Confidence, Lift Rasio.

\section{PENDAHULUAN}

Sistem informasi merupakan hal yang tidak bisa lepas dari suatu organisasi mananapun. Karena suatu organisasi dikatakan efektif dan efisien dalam hal pelayanan organisasi bila organisasi itupun sudah dapat menerapkan prinsipprinsip sistem informasi dalam pelaksanaan kegiatan sehari-hari. Dengan semakin meningkatnya teknologi computer saat ini, sistem informasipun mulai dikembangkan menjadi sistem informasi yang berbasis komputer. Dan CV. Damar Langit merupakan perusahaan milik swasta yang bergerak dalam bidang penjualan, bengkel dan suku cadang. Dalam melaksakan kegiatan operasionalnya CV. Damar Langit 
mendapatkan pasokan bahan baku dari suplier (penyedia). Sistem Informasi Manajemen Inventori adalah sistem informasi yang mengelola data transaksi dan persediaan dalam gudang. Dalam sistem inventori barang biasanya terdiri dari sistem penerimaan barang, sistem pembelian barang, dan sistem gudang. Sistem ini harus dapat memberikan informasi inventori seperti informasi pengeluaran barang, pembelian barang, penerimaan barang dan informasi lain secara cepat dan akurat, selain itu sistem dapat mempermudah kerja user.

Inventori (stock barang) merupakan permasalahan operasional dalam pendistribusian barang ke sub-sub dealer yang sering dihadapi oleh perusahaan. Dalam inventori barang yaitu berupa sepeda motor, yang terdiri dari jumlah barang yang diletakkan di etalase perusahaan atau bisa berupa jumlah sepeda motor yang disimpan di gudang. Jika jumlah inventori terlalu sedikit dan permintaan tidak dapat dipenuhi karena kekurangan persediaan, hal ini akan mengakibatkan customer akan kecewa dan ada kemungkinan customer tidak akan kembali lagi. Begitu juga jika inventori sepeda motor sesuai tipe dan warna terlalu besar, hal ini akan mengakibatkan kerugian bagi perusahaan karena harus menyediakan tempat yang lebih besar, kemungkinan terjadinya penyusutan nilai guna barang (sepeda motor), serta harus menyediakan biayabiaya tambahan yang terkait dengan biaya inventori seperti biaya pemeliharaan dan biaya akuntansi. Karena itu, manajemen harus bisa memutuskan berapa banyak sepeda motor SUZUKI harus disiapkan (distock) yang sesuai tipe dan warna sepeda motor. Selain itu, manajemen juga harus jeli dalam melihat kebutuhan customer sehingga mereka merasa puas karena mendapatkan apa yang dibutuhkannya.

Dan kapan seorang manager dapat menentukan jumlah inventori/persediaan stock sepeda motor yang tepat serta bisa melihat kebutuhan customer dalam pembelian sepeda motor sesuai tipe dan warna yang disukai, manajemen harus sering mengadakan kajian terhadap masalah tersebut. Mereka memerlukan survei pasar dengan mengamati transaksi penjualan, menganalisa data penjualan, mengamati pola/ kebiasaan pembelian sepeda motor sesuai tipe dan warna yang satu dengan tipe dan warna lainnya, mengamati keterkaitan sepeda motor yang dibeli oleh customer, dan kegiatan lain-lainnya.

Oleh karena itu penelitian yang dilakukan berkaitan dengan rancang bangun sistem informasi inventori menggunakan association rules (aturan asosiasi), dapat menentukan pola/ kebiasaan customer dalam membeli sepeda motor SUZUKI sesuai tipe dan warna yang satu dengan tipe dan warna lainnya. Sehingga dari aturan asosiasi ini menghasilkan informasi yang bisa digunakan untuk membantu dalam mendukung keputusan seorang manager dalam manajemen perusahaan terutama dalam memecahkan permasalahan yang berhubungan dengan inventori (persediaan) barang berupa sepeda motor yang sesuai tipe dan warna, sehingga dapat bermanfaat dalam menentukan strategi pemasaran.

Dan untuk itu diperlukan sebuah aplikasi data warehouse yang dilanjutkan dengan analisis menggunakan model dimensional pada OLAP (Online Analitic Processing). Setelah itu dilanjutkan dengan melakukan proses data mining dengan menggunakan metode Association Rule yang ada pada SQL Server (database). Selanjutnya informasi 
tersebut disajikan dengan mengunakan SQL Reporting Services. Sehingga dengan adanya OLAP pada aplikasi program ini berfungsi sebagai salah satu cara untuk menampilakan relational data kepada user sebagai salah satu fasilitas untuk memahami data dan suatu pola yang penting terdapat didalamnya (Nofri Defri Anda, 2002.20).

Sementara pada OLAP digunakan sebagai representasi array multidimensional analisisnya menggunakan model dimensional, sedangkan basis data relational data dimasukkan ke dalam tabel .Sedangkan konsep OLAP pertama di usulkan oleh E.F Codd, bapak dari basis data relational, pada basis data relasional data dimasukkan ke dalam tabel, sementara pada OLAP digunakan representasi array multidimensional.

(http://www.pdfqueen.com)

Dan sistem aplikasi ini diharapkan dapat membantu para pegawai atau pihakpihak yang bersangkutan dalam melaksanakan kegiatan transaksi penerimaan barang dalam pembelian barang. Dalam melakukan pencatatan inventori barang berupa sepeda motor yang sesuai tipe dan warna di CV. Damar Langit tersebut, serta pencatatan sistem transaksi penjualan barang ke (post channel) dan konsumen yang terjadi dalam sub main dealer tersebut. Serta dapat membantu keputusan manager dalam mengambil keputusan didalam sistem sebagai alternatif pemecahan masalah dalam persediaan sepeda motor sesuai tipe dan warna yang tepat dan diminati untuk dibeli oleh konsumen.

\section{SISTEM INFORMASI INVENTORI} Sistem Informasi Manajemen Inventori adalah sistem informasi yang mengelola data transaksi dan persediaan dalam gudang. Perusahaan yang bergerak dibidang produksi umumnya memerlukan Sistem Inventori. Sistem Inventori biasanya terdiri dari sistem penerimaan barang, sistem pembelian barang, dan sistem gudang. Sistem ini harus dapat memberikan informasi inventori seperti informasi pengeluaran barang, pembelian barang, penerimaan barang dan informasi lain secara cepat dan akurat, selain itu sistem dapat mempermudah kerja user (Oka Sudana, 2008:1).

Inventori adalah item atau material yang dipakai oleh suatu organisasi atau perusahaan untuk menjalankan bisnisnya. Jika perusahaan tersebut memproduksi suatu barang atau jasa maka material tersebut digunakan untuk mendukung atau menyediakan kebutuhan produksi. Inventori bagi perusahaan adalah untuk mengantisipasi kebutuhan pelanggan. Begitu juga dalam industri manufacturing, inventori digunakan untuk aktivasi perusahaan yang mana untuk memenuhi pelanggan yang kadang kala tidak dapat diprediksi sehingga kita harus menjaga stock inventory dalam kegiatan produksi. Hal yang tidak dapat diprediksi pun bukan saja terjadi atas pelanggan yang menginginkan barang dari perusahaan kita. inventory juga berperan sebagai buffer dalam hal supply dan demand. Sementara itu, inventory juga berperan sebagai buffer dalam hal supply dan demand, memenuhi customer demand (permintaan atau kebutuhan pelanggan), menyediakan komponenkomponen yang dibutuhkan untuk produksi. (Holy Icun Yunarto Dan Martinus Getty Santika, 2005:1-2).

Dalam manajemen persediaan tersedia sejumlah sistem yang mengatur dan menghitung bagaimana mengisi kembali persediaan barang. Persediaan barang yang ada digudang akan berkurang karena diambil dan dipakai oleh berbagai pihak atau bagian perusahaan. Jumlah, 
frekuensi, keteraturan, dan turun-naiknya pengambilan atau pemakaian tergantung dari kebutuhan. Kebutuhan ini kadangkadang tidak teratur sama sekali. Oleh karena itu, sistem yang dikembangkan untuk pengisian kembali persediaan juga didasarkan atas berbagai kondisi kebutuhan atau permintaan barang (Richardus Eko Indrajit Dan Richardus Djokopranoto, 2003:47)

Konsep persediaan minimummaksimum, secara ideal seharusnya persediaam minimum adalah nol dan persediaan maksimum adalah sebanyak yang secara ekonomis mencapai optimal (Richardus Eko Indrajit Dan Richardus Djokopranoto, 2003: 52).

\section{DATA MINING.}

Data mining adalah suatu proses untuk menemukan suatu interesting knowladge dari sejumlah data yang ada dalam database sehingga didapatkan suatu pattern tertentu yang dapat disimpan sebagai knowladge baru. Interesting knowladge ini biasanya dikenal dengan istilah pattern (pola). Ada beberapa metode dalam data mining salah satunya adalah dengan association rule. Association rule adalah salah satu model data mining yang digunakan untuk mendapatkan hubungan ketergantungan antara item pada sekumpulan record. Misalnya, untuk memprediksi ketergantungan antara dua produk pada sebuah pembelian di toko retail. Ada dua tahap yang harus dilakukan untuk melakukan proses ini, yaitu (1) mencari kombinasi yang paling sering terjadi dalah suatu item set (himpunan item), dan (2) mendefinisikan conditional dan result (akibat). Dalam association rule, ada beberapa ukuran yang sering digunakan. (1) support, (2) confidence, (3) Improvement, dan (4) Certainly Factor (Hanif, 2008:1).
Proses pada data mining ini secara lebih detail terdiri dari lima tahap seperti terdapat pada gambar (2.2).

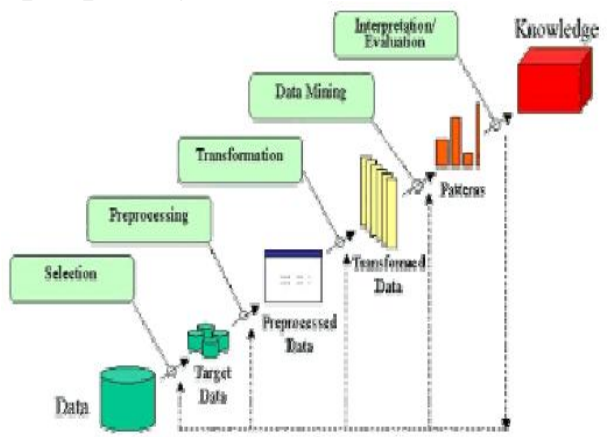

Gambar 2.2. Tahapan-Tahapan Dalam Data Mining.

Tahap-tahapnya dimulai dari pemrosesan raw data (data mentah) sampai pada penyaringan hingga ditemukannya knowledge, dijabarkan sebagai berikut (Adipranata, Rudy dan Handoejo Andreas, 2005:105):

1. Selection, yaitu proses memilih dan memisahkan data berdasarkan beberapa kriteria, misalnya berdasarkan kota tempat tinggal konsumen.

2. Preprocessing, yaitu mempersiapkan data, dengan cara membersihkan data, informasi atau field yang tidak dibutuhkan, yang jika dibiarkan hanya akan memperlambat proses query, misalnya nama pelanggan jika kita sudah mengetahui kode pelanggannya. Selain itu juga, ditahap ini dilakukan penyeragaman format terhadap data yang tidak konsisten, misalnya pada suatu field dari suatu tabel, data jenis kelamin diinputkan dengan "L" atau "M", sedangkan pada tabel yang lain, data tersebut diinputkan sebagai "P" atau "W".

3. Transformation pada tahap ini dilakukan transformasi terhadap data dengan menambahkan data tertentu sehingga membuat data menjadi lebih muda untuk digunakan dan dinavigasikan. 
4. Data mining, tahap ini dipusatkan untuk mendapatkan pola dari data (extraction of data).

5. Interpretation and evaluation, pola yang telah diidentifikasi oleh sistem kemudian di terjemahkan/ diintepretasikan menjadi bentuk knowledge yang lebih mudah dimengerti oleh user untuk membantu pengambilan keputusan, misalnya menunjukan item yang saling berasosiasi melalui grafik atau bentuk lain yang lebih mudah dimengerti.

\section{ALGORITMA APRIORI DAN} ASSOCIATION RULE.

Algoritma a priori termasuk jenis aturan asosiasi pada data mining. Selain $a$ priori, yang termasuk pada golongan ini adalah metode Generalized rule Induction dan Algoritma Hash Based. (Kusrini dan Emha Taufiq L., 2009:149)

Aturan asosiasi (Association rules) atau analisis afinitas (affinity analysis) berkenaan dengan 'studi tentang apa bersama apa'. Ini bisa berupa studi transaksi di supermaket, misalnya seseorang membeli susu bayi juga membeli sabun mandi. Disini berarti susu bayi bersama dengan sabun mandi. Karena awalnya berasal dari studi tentang database transaksi pelanggan untuk menentukan kebiasaan suatu produk dibeli bersama apa, maka aturan asosiasi juga sering dinamakan market basket analysis (Budi Santoso, 2007:225).

Market basket analysis adalah salah satu cara yang digunakan untuk menganalisis data penjualan dari suatu perusahaan. Proses ini menganalisis buying habits konsumen dengan menemukan asosiasi antar item-item yang berbeda yang diletakkan konsumen dalam shopping basket. Hasil yang telah didapatkan ini nantinya dapat dimanfaatkan oleh perusahaan retail seperti toko atau swalayan untuk mengembangkan strategi pemasaran dengan melihat item-item mana saja yang sering dibeli secara bersamaan oleh konsumen (Petra, 2008:1).

Association rule mining adalah suatu prosedur untuk mencari hubungan antar item dalam suatu data set yang ditentukan. Association Rule meliputi dua tahap:

1. Mencari kombinasi yang paling sering terjadi dari suatu itemset.

2. Mendefinisikan Condition dan result (untuk conditional association rule).

Umumnya dua kepercayaan (interesting measure) yang digunakan dalam menentukan suatu aturan association rule, yaitu (Petra, 2008:1):

1. Support: suatu ukuran yang menunjukkan seberapa besar tingkat dominasi suatu item / itemset dari keseluruhan transaksi. Ukuran ini menentukan apakah suatu item / itemset layak untuk dicari confidence faktornya.

2. Confidence: suatu ukuran yang menunjukkan hubungan antar 2 item secara conditional (misal, seberapa sering item B dibeli jika orang membeli item A).

Kedua ukuran ini nantinya berguna dalam menentukan interesting association rules, yaitu untuk dibandingkan dengan batasan (treshold) yang ditentukan oleh user. Batasan tersebut umunya terdiri dari min_support dan min_confidence. Bila memenuhi kedua batasan maka sebuah rule dapat disebut interesting rule.

Confidence adalah rasio antara jumlah transaksi yang meliputi semua item dalam antedent dan concequent dengan jumlah transaksi yang meliputi semua item dalam antecendent atau dapat ditulis: 
Confidence $=$ jumlahtransaksi dengan item dalam antedent (A)dan concequent (B) dibagi Jumlah transaksi dengan item dalam antedent (A)

Dan biasanya pada istilah antecedent untuk mewakili bagian "jika" dan concequent untuk mewakili bagian “maka”. (Budi Santoso, 2007:228)

Lift rasio merupakan salah satu cara yang lebih baik untuk melihat kuat tidaknya aturan asosiasi adalah membandingkan dengan nilai benchmark, dimana kita asumsikan kejadian item dari concequent dalam suatu transaksi adalah independent dengan kejadian dari antecendent dari suatu aturan asosiasi. Atau dengan kata lain, bila item-item dalam antecendent dan concequent saling independent, maka support adalah:

$\underline{\mathrm{P}(\text { antecendent })} * \mathrm{P}($ concequent $)=\mathrm{P}($ conseq uent)

$\mathrm{P}$ (antecendent)

Nilai estimasi dari confidence benchmark dihitung dari suatu aturan yang dihitung dengan:

Confidence benchmark $=$ jumlah transaksi dg item dalam concequent(B) dibagi Jumlah transaksi dalam database

Kita bandingkan confidence terhadap confidence benchmark dengan melihat rasionya, yang dinamakan lift rasio. Jadi lift rasio adalah perbandingan antara confidence untuk suatu aturan dibagi dengan confidence, dimana diasumsikan consequent dan antencedent saling independent.

$$
\text { Lift rasio }=\frac{\text { confidence }}{\text { Benchmark confidence }}
$$

Nilai lift rasio lebih besar dari 1 menunjukkan adanya manfaat dari aturan tersebut. Lebih tinggi lift rasio, lebih besar kekuatan asosiasi.(Budi Santoso, 2007: 229-230).

\section{OLAP (Online Analitycal \\ Processing).}

OLAP merupakan salah satu dari teknik data mining. Tidak semua yang dapat digunakan untuk menganalisa data merupakan data mining. OLAP adalah suatu cara untuk menampilkan relational data kepada user sebagai salah satu fasilitas untuk memahami data dan suatu pola yang penting yang terdapat didalamnya. Seperti pada suatu penggambaran, OLAP bukan merupakan suatu alat yang penting untuk menggambarkan informasi. Metode OLAP yang sering digunakan berdasarkan multidimensional databases (MDDs). MDDs adalah suatu representasi data yang memungkinkan pengguna untuk lebih dalam melihat data pada suatu kesimpulan yang bervariasi. (Nofri Defri Anda, 2002:20).

\section{Operasi-Operasi OLAP}

a) Slicing dan dicing.

Slicing dan dicing adalah operasi untuk melihat data sebagai visualisasi dari kubus. Dengan slicing dan dicing pengguna dapat melihat data dari beberapa perpestif. Slicing memotong kubus sehingga dapat memfokuskan pada perspektif yang spesifik (pada suatu dimensi). Sedangkan pada dicing memberikan kemampuan untuk melihat pemilihan data pada dua dimensi atau lebih, yaitu dengan merotasi cube pada perpekstif yang lain sehingga pengguna dapat melihat lebih spesifik terhadap data yang di analisa.

\section{b) Roll up dan drill down.}

Roll up dan drill down adalah operasi untuk melihat data global atau detail di 
sepanjang level hirarki dimensi. Roll up untuk melihat data secara global atau rangkuman (summary). Drill down memandu pengguna untuk memeperoleh data yang lebih detail. Drill down ini biasa digunakan untuk menjawab pertanyaan atas suatu kasus tertentu. Misalnya untuk menjawab pertanyaan ketika sebuah summary number (rata-rata jumlah) di bawah atau di atas harapan.

\section{DELPHI 7.0.}

Borland Delphi merupakan suatu bahasa pemrograman yang memberikan berbagai fasilitas pembuatan aplikasi visual. Keunggulan bahasa pemrograman ini terletak pada produktivitas, kualitas, pengembangan perangkat lunak, kecepatan kompilasi, pola desain yang menarik serta diperkuat dapat digunakan untuk merancang program aplikasi yang dimiliki tampilan seperti program aplikasi lain yang berbasis windows.

Bahasa Pemrograman Delphi termasuk dalam salah satu bahasa pemrograman visual adalah generasi lanjut pemrograman pascal. Adapun, rilis pertamanya (versi Delphi pertama) adalah tahun 1995, kemudian berlanjut sampai rilis ketujuh pada tahun 2002. Pemrograman Delphi sendiri dibuat oleh Borland International Corporation dan berjalan di atas platform (sistem operasi) Windows, sedangkan sebagai pengetahuan yang berjalan di atas platform (sistem operasi) Linux adalah Kylic, yang merupakan saudara kembar pemrograman Delphi. (Jamaluddin, 2005: 1)

Delphi adalah software buatan Borland yang sangat populer. Berbeda dengan software Windows umumnya, Delphi bukanlah software aplikasi seperti MS Office atau permainan game. Delphi adalah sebuah bahasa pemrograman, Development Language, aplikasi untuk membuat aplikasi. Delphi digunakan untuk membangun Windows, aplikasi grafis, aplikasi visual, bahkan aplikasi jaringan (client/server) dan berbasis internet. (Husni, 2004: 1)

Secara umum, kemampuan Delphi adalah menyediakan komponenkomponen dan bahasa pemrograman yang andal, sehingga memungkinkan untuk membuat program aplikasi sesuai dengan keinginan, dengan tampilan dan kemampuan yang canggih.

\section{INTERBASE.}

Interbase merupakan program aplikasi database untuk menangani dan mengelola database oleh sebuah perangkat lunak yang sangat terkenal, yaitu Borland. Interbase dapat ditemukan dalam satu paket dengan program Delphi. Tujuannya adalah agar pemakai lebih mudah mengakses data. Delphi merupakan program aplikasi database berbasis Windows yang menyertakan banyak komponen untuk mengakses database dan mempresentasikan isi dari informasi (Bambang Robi'in, 2002:10).

\section{ANALISIS SISTEM}

Untuk membuat suatu aplikasi dibutuhkan sebuah perencanaan terlebih dahulu pada alur kerja dari sistem yang diharapkan. Pada tahap perencanaan ini akan dijelaskan dua hal yaitu deskripsi sistem dan batasan sistem.

\section{A. Deskripsi Sistem}

Untuk memperoleh gambaran aplikasi ini yang berkaitan dengan rancang bangun sistem informasi inventori menggunakan metode association rules (aturan asosiasi) ini adalah berbentuk client-server. Dengan sistem secara semi online (local network) akan memberikan manfaat baik dari segi ekonomi kepada petugas maupun manager perusahaan. 
Pada client berfungsi sebagai operator yang bertugas sebagai penginput datadata barang masuk. Sedangkan manager sebagai server sekaligus pengawas jalannya sistem dan sekaligus melihat informasi inventori sepeda motor di gudang dan mengamati pola transaksi konsumen dalam membeli sepeda motor sesuai tipe dan warna dari dataset transaksi yang dijalankan pada aplikasi program sistem informasi inventori didalam database.

Sehingga pada manager berfungsi sebagai server untuk aplikasi program ini. Dari server ini seorang pimpinan operasional dapat mengetahui dan memliki hak akses seluruh isi form dalam sistem aplikasi program sistem informasi inventori sepeda motor. Dan dapat mengetahui sistem yang dapat mendukung keputusan dalam persediaan sepeda motor SUZUKI sesuai tipe dan warna di perusahan tersebut berdasarkan analisa data penjualan melalui form aplikasi "OLAP (Online Analitical Processing). Selanjutnya pimpinan operasional perusahaan di CV. Damar Langit dapat merencanakan jumlah pemesanan atau pembelian sepeda motor SUZUKI pada masa periode selanjutnya ke main dealer. Hal ini untuk menambah stok di gudang. Sedangkan jumlah persediaan (inventori) diperoleh dari hasil penyimpanan yang diproses ke dalam database.

Dengan adanya OLAP tersebut seorang manager (Pimpinan operasional) Di CV. Damar Langit dapat menganalisa dari data warehouse untuk mengetahui pola/ kebiasaan konsumen (customer) dalam membeli sepeda motor sesuai tipe dan warna yang satu dengan tipe dan warna lainnya dengan melihat nilai prosentase yang paling di dominasi dari aturan asosiasi final.

\section{B. Batasan Sistem}

Dalam batasan sistem yang akan dirancang dan direncanakan dalam aplikasi rancang bangun sistem informasi inventori dengan menggunakan metode association rules adalah menjelaskan dua hal yaitu berupa:

Identifikasi kebutuhan software dan hardware yang digunakan untuk pengujian aplikasi dalam sistem ini adalah:

1. Windows XP SP2

2. Borland Delphi 7.0

Delphi 7.0 dalam hal ini adalah tool bahasa pemrograman yang digunakan untuk mengimplementasikan program yang sudah dirancang dengan metode association rule.

3. Interbase

Untuk merancang basis data dalam program ini, peneliti menggunakan Interbase 6.5.

4. Power Designer (Prosess Analyst) versi 6.0.0 32 bit.

Power Designer (Prosess Analyst merupakan sebuah tool pemodelan visual,. Dengan tool ini dapat dilakukan sebuah perancangan dan desain sistem.

Sedangkan spesifikasi perangkat keras yang direncanakan pada client-server menggunakan jaringan komputer ini adalah sebagai berikut:

Dua buah komputer masing-masing:

a. Komputer 1, dengan spesiiikasi:

- Operating System : Microsott Windows XP.

- Processor : Intel $®$ Pentium 4 CPU $2.66 \mathrm{GHz}$

- RAM (Read Access Memory) : $768 \mathrm{MB}$

- Card LAN atau NIC (Network Interface Card) : Realtek RTL8139 Family PCI Fast Ethernet NIC. Card LAN ini 
digunakan agar sebuah komputer dapat terhubung ke suatu jaringan.

b.Komputer 2 (LAPTOP), dengan spesitikasi:

- Operating System: Microsoft Windows XP.

- Processor: Intel Core To Duo.

- $\quad$ RAM (Read Access Memory): $1 \mathrm{~GB}$.

- Card LAN atau NIC (Network Interface Card). Atheros AR8121/AR8113/AR8114

PCI-E Ethernet Controller. Card LAN ini digunakan agar sebuah komputer dapat terhubung.

\section{PERANCANGAN SISTEM.}

Sistem yang dirancang dalam jaringan computer untuk uji coba pada sistem informasi inventori menggunakan metode association rule ini adalah: pada server sebagai admin (Manager) melakukan ke address pada port tertentu. Client (operator) melakukan mekanisme join ke alamat server. Join disini berarti client juga mengirim stream media ke alamat yang dibuat server. Apabila stream media dari operator telah diterima oleh server maka computer client dapat mengirim data ke database server yang telah dikirim oleh operator. Sedangkan gambaran penelitian, untuk memodelkan sistem secara keseluruhan digambarkan pada diagram blok sistem pada Gambar 1 .

\section{HASIL UJI COBA SISTEM.}

\section{a. Data Uji Coba.}

Aplikasi diterapkan dengan memasukkan data stok, data pembelian, data penjualan, data konsumen data supplier (main dealer). Adapun jumlah data yang dimasukkan adalah seperti dalam Tabel 1.

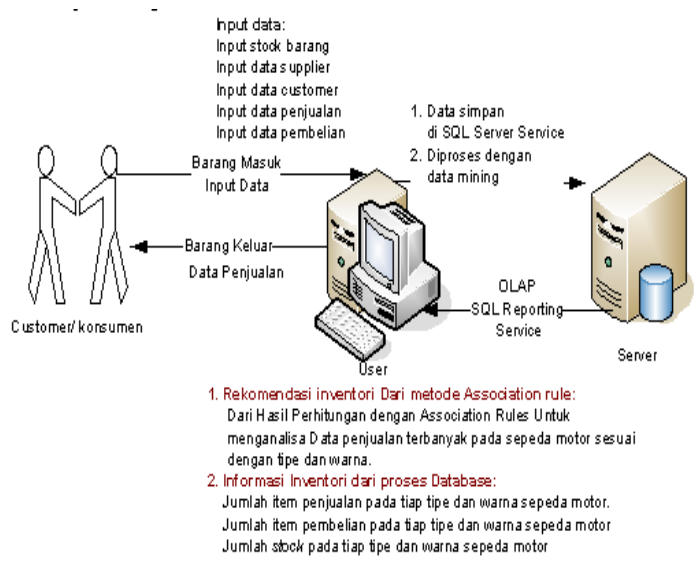

Gambar 1. Diagram Blok Sistem

Tabel 1. Data Uji Coba.

\begin{tabular}{|l|l|l|}
\hline No & \multicolumn{1}{|c|}{ Kriteria } & \multicolumn{1}{|c|}{ Jumlah } \\
\hline 1 & $\begin{array}{l}\text { Data stok sepeda motor dan } \\
\text { data pembelian tanggal 1 } \\
\text { oktober 2008-29 November } \\
2008 .\end{array}$ & 135 unit \\
\hline 2 & Data penjualan & 53 unit \\
\hline 3 & Konsumen & $\begin{array}{l}41 \text { (atas nama } \\
\text { perorangan an } \\
\text { perusahaan) }\end{array}$ \\
\hline 4 & Dealer & 2 perusahaan \\
\hline
\end{tabular}

Dan dari data-data tersebut yang digunakan sampel dalam uji coba aplikasi "Rancang Bangun Sistem Informasi Inventori Menggunakan Metode Association Rules Di CV. Damar Langit" adalah sepeda motor dari produk suzuki didalam gudang.

\section{b. Generate Data.}

Dari hasil uji coba pada analisa data Dengan Teknik OLAP (Online Analytical Processing). Sedangkan data yang digunakan adalah pada periode 1 oktober 2008-29 November 2008. Maka hasil implementasi dari visualisasi program adalah mempunyai 42 titik transaksi dalam penjualan sepeda motor dengan 16 itemset sepeda motor sesuai tipe dan warna yang muncul. Maka hal ini dapat dilihat pada Gambar 2. 


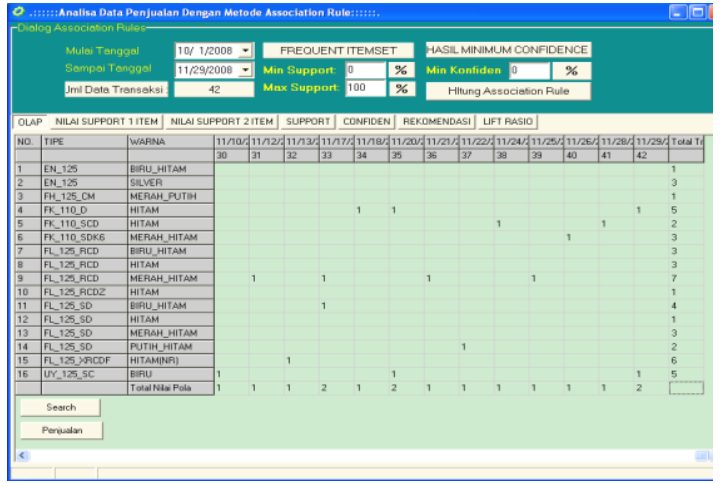

Gambar 2. Hasil Analisa Data OLAP.

\section{c. Nilai Support 1 Item dan Nilai Support 2 Item.}

Sedangkan nilai support satu item di peroleh dengan rumus sebagai berikut:

Support(A):Jml Transaksi mengandung A Total Transaksi.

Sedangkan nilai support dari 2 item diperoleh dengan rumus sebagai berikut:

Support(A,B): $\underline{\text { Tranaksi A\&B }}$

Total Transaksi.

Dan hasil perhitungan nilai satu support item dari implementasi program, dapat dilihat pada gambar $(3 . a, b)$ yaitu sebagai berikut:

\begin{tabular}{|c|c|c|c|c|c|}
\hline OLAP & NILAI SUPPORT 1 ITEM NI & NILAI SUPPORT 2 ITEM & SUPPORT & CONFIDEN & REKOMENDASI \\
\hline No & Dataset 1 llem & Jumlah Transaksi & i Hilungan & & Wilia Support (\%) \\
\hline 1 & EN_125·BIRU_HITAM & 1 & $1 / 42 \times 100$ & & $2.38 \%$ \\
\hline 2 & EN__25-SLLVER & 3 & $3 / 42100$ & & 7.14\% \\
\hline 3 & FH_125_CM - MERAH_PUTHH & 1 & $1 / 42 \times 100$ & & $238 \%$ \\
\hline 4 & FK__110_D · HITAM & 5 & $5 / 42 \times 100$ & & $11.90 \%$ \\
\hline 5 & FK_110_SCD · HITAM & 2 & $2 / 42 \times 100$ & & $4.76 \%$ \\
\hline 6 & FK_110_SDKG - MERAH__HITAM & 3 & $3 / 42100$ & & 7.14\% \\
\hline 7 & FL__125_RCD · BIRU_HITAM & 3 & $3 / 42 \times 100$ & & 7.14\% \\
\hline 8 & FL__125_RCD · HITAM & 3 & $3 / 42 \times 100$ & & $7.14 \%$ \\
\hline 9 & FL_125_RCD - MERAH_HITTMM & 7 & $7 / 42 \times 100$ & & $16.67 \%$ \\
\hline 10 & FL_125_RCDZ - HITAM & 1 & $1 / 42^{2} 100$ & & $2.38 \%$ \\
\hline 11 & FL_125_SD - BIRU_HITAM & 4 & $4 / 42100$ & & $9.52 \%$ \\
\hline 12 & FL__ $125 \_S D \cdot H I T A M$ & 1 & $1 / 42 \times 100$ & & $233 \%$ \\
\hline 13 & FL_125_SD - MERAH__HITAM & 3 & $3 / 42 \times 100$ & & 7.14\% \\
\hline 14 & FL_125_SD PPUTH_HITAMM & 2 & $2 / 42 \times 100$ & & $4.76 \%$ \\
\hline 15 & FL_125_XRCDF·HITAM(NR) & 6 & $6 / 42 \times 100$ & & $14.29 \%$ \\
\hline 16 & UYY_125_SC. BRI & 5 & $5 / 42 \times 100$ & & 11.90\% \\
\hline
\end{tabular}

(a)

\begin{tabular}{|c|c|c|c|c|c|c|}
\hline OLAP & NILAI SUPPORT 1 ITEM & NILAI SUPPORT 2 ITEM & SUPPORT & CONFIDEI & \begin{tabular}{l|l} 
N REKOMENDAS & RE
\end{tabular} & LIFT RASIO \\
\hline No & Dataset 21tem & & Jumlah $\mathrm{T}$ & ransaksi & Perhitungan & Niliai Support 1\% \\
\hline 1 & EN_125.SILVER ;FK_110_D. & HITAM & 1 & & \multicolumn{2}{|c|}{ Jml Tr $(A-B) /$ Tot Tr ${ }^{*} 2.38 \%$} \\
\hline 2 & EN_125.SILVER :UY_125_SC & C.BIRU & 2 & & \multicolumn{2}{|c|}{$\operatorname{Jml} \operatorname{Tr}(A-B) / \operatorname{Tot} T_{1} \times 4.76 \%$} \\
\hline 3 & FK_110_D.HITAM :FL_125_X & XRCDF-HITAM(NR) & 1 & & \multicolumn{2}{|c|}{$\operatorname{Jml} \operatorname{Tr}(A-B) / \operatorname{Tot} \operatorname{Tr} \times 2.38 \%$} \\
\hline 4 & FK_110_DHHITAM :UY_125_ & SCBIRU & 3 & & \multicolumn{2}{|c|}{$\operatorname{Jml} \operatorname{Tr}(A-B) / \operatorname{Tot} \operatorname{Tr} \times 7.14 \%$} \\
\hline 5 & FL_125_RCD_MERAH_HITTAM & M:FL_125_SD.BIRU_HITAM & M] 2 & & \multicolumn{2}{|c|}{$\operatorname{Jml} \operatorname{Tr}(A-B) / \operatorname{Tot} \operatorname{Tr}^{*} 4.76 \%$} \\
\hline
\end{tabular}

(b)

Gambar 3. (a) Hasil Perhitungan Nilai Support Satu Item dan (b). Nilai Support Dua Item.

\section{d. Frequent Itemset.}

Untuk hasil perhitungan nilai support 1 item sampai 2 item ini, dicari nilai frequence itemset dengan menentukan batasan (threshold) dengan cara menentukan nilai minimum support sampai maksimum support yang ditentukan oleh user, Misalnya ditentukan nilai thresholdnya $=0 \%$, maka beberapa item yang muncul adalah seperti pada Gambar (4),yang tamapak dari implementasi program..

\begin{tabular}{|c|c|c|}
\hline OLAP & NILAI SUPPORT 1 ITEM | NILAI SUPPORT 2 ITEM & SUPPORT \\
\hline \multicolumn{3}{|c|}{ HASIL } \\
\hline No & Frequent Itemset & Support \\
\hline 1 & EN_125-BIRU_HITAM & $2.38 \%$ \\
\hline 2 & EN_125 - SILVER & $7.14 \%$ \\
\hline 3 & FH_125_CM - MERAH_PUTIH & $2.38 \%$ \\
\hline 4 & FK_110_D - HITAM & $11.90 \%$ \\
\hline 5 & FK_110_SCD $\cdot$ HITAM & $4.76 \%$ \\
\hline 6 & FK_110_SDK6 - MERAH_HITAM & $7.14 \%$ \\
\hline 7 & FL_125_RCD - BIRU_HITAM & $7.14 \%$ \\
\hline 8 & FL_125_RCD - HITAM & $7.14 \%$ \\
\hline 9 & FL_125_RCD - MERAH_HITAM & $16.67 \%$ \\
\hline 10 & FL_125_RCDZ - HITAM & $2.38 \%$ \\
\hline 11 & FL_125_SD - BIRU_HITAM & $9.52 \%$ \\
\hline 12 & FL_125_SD - HITAM & $2.38 \%$ \\
\hline 13 & FL_125_SD - MERAH_HITAM & $7.14 \%$ \\
\hline 14 & FL_125_SD - PUTIH_HITAM & $4.76 \%$ \\
\hline 15 & FL_125_XRCDF - HITAM(NR) & $14.29 \%$ \\
\hline 16 & UY_125_SC - BIRU & $11.90 \%$ \\
\hline 17 & EN_125-SILVER ; FK_110_D-HITAM & $2.38 \%$ \\
\hline 18 & EN_125-SILVER : UY_125_SC-BIRU & $4.76 \%$ \\
\hline 19 & FK_110_D-HITAM ; FL_125_XRCDF-HITAM(NR) & $2.38 \%$ \\
\hline 20 & FK_110_D-HITAM : UY_125_SC-BIRU & $7.14 \%$ \\
\hline 21 & FL_125_RCD-MERAH_HITAM : FL_125_SD-BIRU_HITAM & $4.76 \%$ \\
\hline
\end{tabular}




\section{e. Confidence.}

Confidence adalah rasio antara jumlah transaksi yang meliputi semua item dalam antedent dan concequent dengan jumlah transaksi yang meliputi semua item dalam antecendent atau dapat ditulis:

\section{Confidence $=$}

jumlah transaksi dengan item dlm antedent(A)dan concequent(B)

Jumlah transaksi dengan item dalam antedent $(\mathrm{A})$

Sedangkan hasil nilai confidence adalah sebagai berikut:

\begin{tabular}{|c|c|c|c|c|c|}
\hline OLAP & NILAI SUPPORT 1 ITEM | NILAI SUPPORT 2 ITEM | S & SUPPORT & CONFIDEN REK & REKOMENDASI & LIFT RASIO \\
\hline \multicolumn{6}{|c|}{-Nilai Konfiden } \\
\hline No & ItemSet & & Jumlah Transaksi & \begin{tabular}{l|l} 
ksi & Perhitungan
\end{tabular} & Nilai Con \\
\hline 1 & EN_125:SILVER=FF__110_D.HITAM & & 1 & $1 / 3 \times 100$ & 33.33 \\
\hline 2 & EN_125.SILVER $\Rightarrow$ \UY_125_SC.BIRU & & 2 & $2 / 3 \times 100$ & 66.67 \\
\hline 3 & FK__110_D.HITAM=FFL_125_XRCDF.HITAM(NR) & & 1 & $1 / 5 \times 100$ & 20.00 \\
\hline 4 & FK_110_D.HITAM $\Rightarrow \backslash U Y \_125$ SSCBIRU & & 3 & $3 / 5 \times 100$ & 60.00 \\
\hline 5 & FL_125_RCD-MERAH_HITAM $\Rightarrow F L$ _125_SD-BIRU_HITAM & & 2 & $2 / 7 \times 100$ & 28.57 \\
\hline 6 & FK_110_D.HITAM $\Rightarrow E$ EN_125.SLLVER & & 1 & $1 / 5 \times 100$ & 20.00 \\
\hline 7 & 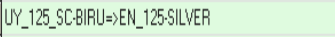 & & 2 & $2 / 5 \times 100$ & 40.00 \\
\hline 8 & FL_125_XRCDF.HITAM(NR)=PFK_110_D.HITAM & & 1 & $1 / 6 \times 100$ & 16.67 \\
\hline 9 & UY_125_SC.BRIRJ $=$ FK_ 110_D.HITAM & & 3 & $3 / 5 \times 100$ & 60.00 \\
\hline 10 & FL_125_SD.BIRU_HITAM =FFL_125_RCD-MERAH_HITAM & & 2 & $2 / 4 \times 100$ & 50.00 \\
\hline
\end{tabular}

Gambar 5. Hasil Nilai Confidence.

\section{f. Rekomendasi Dari aturan Asosiasi Final}

Pada form rekomendasi ini dari aturan asosiasi ini menghasilkan informasi yang bisa digunakan untuk membantu dalam mendukung keputusan seorang manager untuk pengambilan keputusan dalam manajemen perusahaan terutama dalam memecahkan permasalahan yang berhubungan dengan inventori (persediaan) barang berupa sepeda motor yang sesuai tipe dan warna, sehingga dapat bermanfaat dalam menentukan strategi pemasaran. Yang menggunakan aturan rumus:

Aturan asosiasi final=nilai support $*$ confidence terbesar.
Tabel 2. Hasil Perhitungan Nilai Aturan asosiasi Final.

\begin{tabular}{|c|c|c|c|}
\hline Aturan & $\begin{array}{c}\text { Supp } \\
\text { ort }\end{array}$ & $\begin{array}{c}\text { Confid } \\
\text { ence }\end{array}$ & $\begin{array}{c}\text { Supp* } \\
\text { Conf }\end{array}$ \\
\hline EN_125-SILVER $\Rightarrow$ & 2.38 & 33.33 & $0.79 \%$ \\
\hline FK_110_D-HITAM & $\%$ & $\%$ & \\
\hline $\begin{array}{l}\text { EN_125-SILVER } \Rightarrow \\
\text { UY_125 SC-BIRU }\end{array}$ & $\begin{array}{c}4.76 \\
\%\end{array}$ & $\begin{array}{c}66.67 \\
\%\end{array}$ & $3.17 \%$ \\
\hline $\begin{array}{l}\text { FK_110_D-HITAM } \\
\Rightarrow \text { FL_125_XRCDF- } \\
\text { HITAM(NR) }\end{array}$ & $\begin{array}{c}2.38 \\
\%\end{array}$ & $\begin{array}{c}20.00 \\
\%\end{array}$ & $0.48 \%$ \\
\hline $\begin{array}{l}\text { FK_110_D-HITAM } \\
\Rightarrow \text { UY_125_SC- } \\
\text { BIRU }\end{array}$ & $\begin{array}{c}7.14 \\
\%\end{array}$ & $\begin{array}{c}60.00 \\
\%\end{array}$ & $4.28 \%$ \\
\hline $\begin{array}{l}\text { FL_125_RCD- } \\
\text { MERAH_HITAM } \Rightarrow \\
\text { FL_125_SD-BIRU- } \\
\text { HITAM }\end{array}$ & $\begin{array}{c}4.76 \\
\%\end{array}$ & $\begin{array}{c}28.57 \\
\%\end{array}$ & $1.36 \%$ \\
\hline $\begin{array}{l}\text { FK_110_D- } \\
\text { HITAM } \Rightarrow \text { EN_125- } \\
\text { SILVER }\end{array}$ & $\begin{array}{c}2.38 \\
\%\end{array}$ & $\begin{array}{c}20.00 \\
\%\end{array}$ & $0.48 \%$ \\
\hline $\begin{array}{l}\text { UY_125_SC- } \\
\text { BIRU } \Rightarrow E N \_125- \\
\text { SILVER }\end{array}$ & $\begin{array}{c}4.76 \\
\%\end{array}$ & $\begin{array}{c}40.00 \\
\%\end{array}$ & $1.90 \%$ \\
\hline $\begin{array}{l}\text { FL_125_XRCDF- } \\
\text { HITAM(NR) } \Rightarrow \\
\text { FK_110_D-HITAM }\end{array}$ & $\begin{array}{c}2.38 \\
\%\end{array}$ & $\begin{array}{c}16.67 \\
\%\end{array}$ & $0.40 \%$ \\
\hline $\begin{array}{l}\text { UY_125_SC-BIRU } \\
\Rightarrow \text { FK_110_D- } \\
\text { HITAM }\end{array}$ & $\begin{array}{c}7.14 \\
\%\end{array}$ & $\begin{array}{c}60.00 \\
\%\end{array}$ & $4.28 \%$ \\
\hline $\begin{array}{l}\text { FL_125_SD-BIRU- } \\
\text { HITAM } \Rightarrow \\
\text { FL_125_RCD- } \\
\text { MERAH-HITAM }\end{array}$ & $\begin{array}{c}4.76 \\
\%\end{array}$ & $\begin{array}{c}50.00 \\
\%\end{array}$ & $2.38 \%$ \\
\hline
\end{tabular}

Nilai tertinggi dari aturan asosiasi final ini dijadikan data rekomendasi dan sebagai sistem pengambilan keputusan dalam persediaan sepeda motor SUZUKI sesuai tipe dan warna pada tabel 3.

Tabel 3. Hasil Perhitungan Nilai Maksimum Dari Aturan Asosiasi Final.

\begin{tabular}{|l|l|l|l|l|}
\hline $\begin{array}{l}\text { N } \\
\text { o. }\end{array}$ & Aturan & $\begin{array}{l}\text { Supp } \\
\text { ort }\end{array}$ & $\begin{array}{l}\text { Confi } \\
\text { dence }\end{array}$ & $\begin{array}{l}\text { Supp* } \\
\text { Conf }\end{array}$ \\
\hline 1. & $\begin{array}{l}\text { FK_110_D- } \\
\text { Hitam } \Rightarrow \\
\text { UY_125 SC- } \\
\text { Biru }\end{array}$ & $\begin{array}{l}7,14 \\
\%\end{array}$ & $60 \%$ & $4.28 \%$ \\
\hline 2. & $\begin{array}{l}\text { UY_125_SC- } \\
\text { Biru } \Rightarrow \text { FK_110 } \\
\text { D-Hitam }\end{array}$ & $\begin{array}{l}7,14 \\
\%\end{array}$ & $60 \%$ & $4,28 \%$ \\
\hline
\end{tabular}


1

\section{g. Hasil Informasi Stok.}

Sedangkan Hasil Informasi Stok didapatkan dari hasil jumlah pembelian dikurangi jumlah penjualan, perhatikan pada gambar 8 .

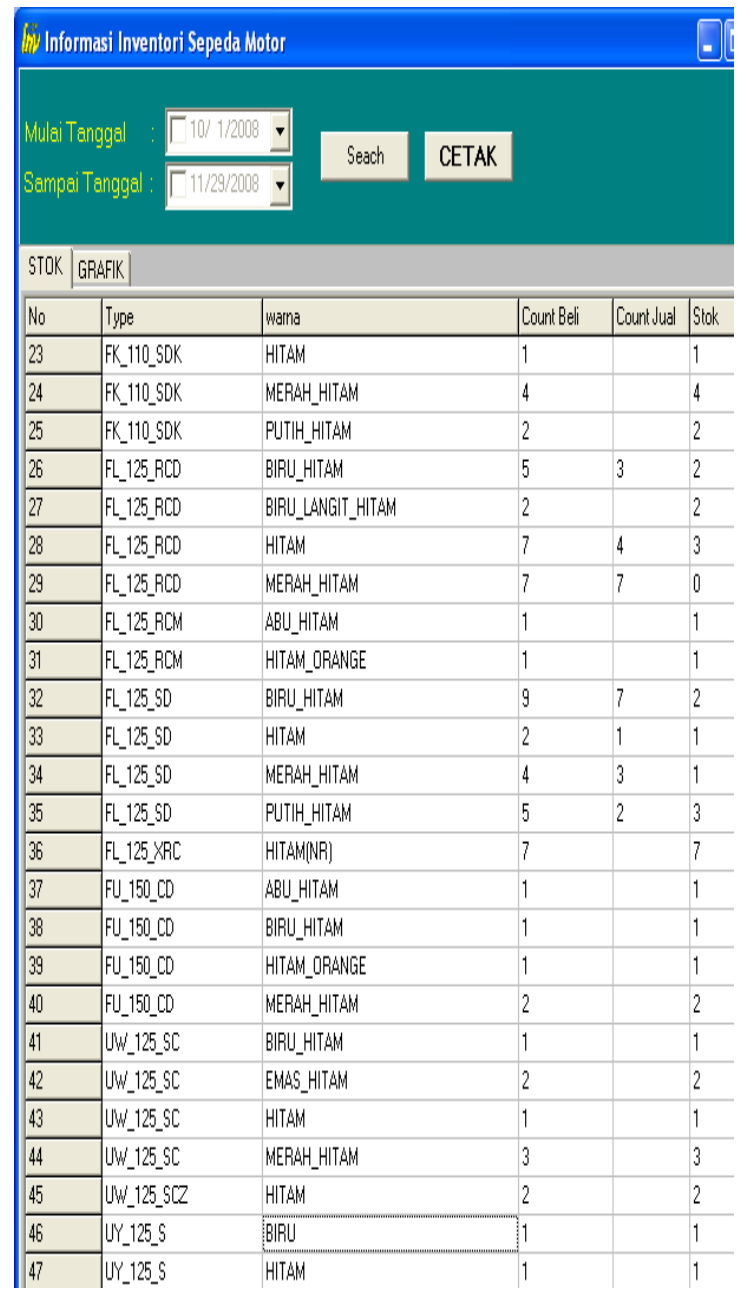

Gambar 8. Hasil Stok Akhir Dari Hasil Implementasi Program.

\section{h. Nilai Lift Rasio.}

Lift rasio merupakan salah satu cara yang lebih baik untuk melihat kuat tidaknya aturan asosiasi adalah membandingkan dengan nilai benchmark. Yang menggunakan aturan rumus:

$$
\text { Lift rasio }=\frac{\text { confidence }}{\text { Benchmark confidence }} \text {. }
$$

Confidence benmark $=$ jumlah transaksi item dalam concequent. Jumlah transaksi dalam database.

\begin{tabular}{|c|c|c|c|c|c|c|c|}
\hline \multicolumn{8}{|l|}{ IITPKSID } \\
\hline No lonset & 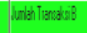 & Pathrgan & 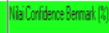 & 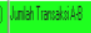 & Pethenga & 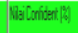 & than \\
\hline 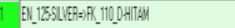 & 5 & 50610 & 1190 & 1 & 181010 & 3933 & 280 \\
\hline 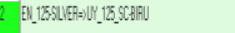 & 5 & 50010 & 11.90 & 2 & 283100 & 867 & 560 \\
\hline 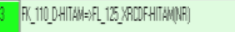 & 6 & BECTO & 1420 & 1 & 1570 & 2000 & 1.40 \\
\hline 4 R. & 5 & 50010 & 1110 & 3 & 35700 & 2000 & 504 \\
\hline 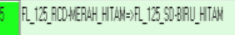 & 4 & uecolo & 952 & 2 & $2 n 100$ & 2857 & 300 \\
\hline 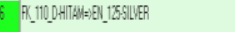 & 3 & 36070 & 714 & 1 & 15100 & 2000 & 280 \\
\hline 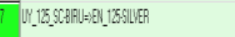 & 3 & 30100 & 714 & 2 & 2510 & 4000 & 500 \\
\hline 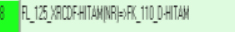 & 5 & 54070 & 1190 & 1 & 1870 & 1667 & 140 \\
\hline 9 UY $18 S C A P U=R$ R_110DHTH & 5 & 50010 & 1190 & 3 & 3910 & w00 & 504 \\
\hline 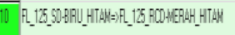 & 1 & 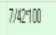 & 1667 & 2 & 24100 & 5000 & 300 \\
\hline
\end{tabular}

Gambar 7. Hasil Perhitungan Lift Rasio.

Fungsi dari lift rasio ini adalah untuk megetahui ukuran kuat dan tidaknya hubungan asosiasi pada hubungan satu item dengan satu item lainnya. Dan tiap 1 item mengandung tipe dan warna sepeda motor. Nilai lift rasio lebih besar dari satu menunjukkan adanya manfaat dari aturan tersebut. Lebih tinggi nilai lift rasio, lebih besar kekuatan asosiasi pada itemset yang muncul.

Nilai lif rasio lebih besar dari 1 menunukkan adanya manfaat dari aturan tersebut. Lebih tinggi nilai lif rasio, lebih besar kekuatan asosiasinya. Sedangkan hasil perhitungan lift rasio dapat dilihat pada gambar 7 di atas.

\section{i. Analisa Hasil}

Hasil analisa data penjualan pada nilai tertinggi dari aturan asosiasi untuk rekomendasi persediaan sepeda motor sesuai tipe dan warna yaitu sebagai berikut: UY $125 \mathrm{SC}=$ Biru $\Rightarrow$ FK 110 $\mathrm{D}=$ Hitam dengan nilai support $7,14 \%$ dan confidence $60 \%$ dengan memperoleh nilai lift rasio yaitu 2,80. Sedangkan hubungan asosiasi pada item tersebut dan yang membedakan masing-masing tipe dan warna pada sepeda motor SUZUKI adalah berdasarkan spesifikasi dari tipe 
itu sendiri yaitu: FK $110 \mathrm{D} \Rightarrow$ UY 125 $\mathrm{SC}=$ Biru $=$ Hitam artinya bila seseorang membeli Spin CW berpelg bintang dengan warna biru, maka juga berkaitan membeli sepeda motor yang bermerek Smash, rem tromol dengan warna hitam. Untuk lebih detailnya lihat pada lampiran-lampiran (data keterangan format penulisan sepeda).

Sedangkan hasil implementasi pada aplikasi informasi inventori untuk informasi stok yang diproses melalui database pada tipe: "UY 125 SC" dengan warna "Biru" =2 buah unit sepeda motor dan Tipe: "FK 110 D" dengan warana "Hitam" = 2 unit sepeda motor.

\section{KESIMPULAN DAN SARAN.}

Pada penerapan sistem informasi inventori menggunakan metode association rule ini adalah sebagai sistem pengambilan keputusan untuk merekomendasikan persediaan sepeda motor SUZUKI berdasarkan tipe dan warna dan menyediakan beberapa informasi lain seperti data penjualan, data pembelian, data stok. Sedangkan hasil analisa uji coba tanggal 1 oktober 2008 sampai 29 November 2008 adalah sebagai berikut: UY 125 SC=Biru $\Rightarrow$ FK 110 $\mathrm{D}=$ Hitam dengan nilai support $7,14 \%$ dan confidence $60 \%$ dengan memperoleh nilai lift rasio yaitu 2,80. Sedangkan hubungan asosiasi pada item tersebut dan yang membedakan masing-masing tipe dan warna pada sepeda motor SUZUKI adalah berdasarkan spesifikasi dari tipe itu sendiri yaitu: FK $110 \mathrm{D} \Rightarrow$ UY 125 $\mathrm{SC}=$ Biru $=$ Hitam artinya bila seseorang membeli Spin $\mathrm{CW}$ berpelg bintang dengan warna biru, maka juga berkaitan membeli sepeda motor yang bermerek Smash, rem tromol dengan warna hitam.

Sedangkan hasil implementasi pada aplikasi informasi inventori untuk informasi stok yang diproses melalui database pada tipe: "UY 125 SC" dengan warna "Biru" $=2$ buah unit sepeda motor dan Tipe: "FK 110 D" dengan warana "Hitam" = 2 unit sepeda motor.

\section{DAFTAR PUSTAKA.}

[1]. Andri Kristanto. 2003. Perancangan Sistem Informasi Dan Aplikasinya, Penerbit Gava Media: Yogyakarta.

[2]. Antony Pranata, 2000. Pemograman Borland Delphi. Andi: Yogyakarta.

[3]. Antony Pranata. 2003. Pemograman Borland delphi 6. Andi: Yogyakarta.

[4]. Agung Toto Wibowo. 2007. Berbagai Makalah Sistem Informasi 2007 (KNSI 2007),. Sekolah Tinggi Teknologi Telkom: Bandung.

[5]. Arbie. 2004. Manajemen Database Dengan MySQL. Yogyakarta: Andi.

[6]. Budi Prijanto. 2008. Penilaian persediaan: pendekatan kost (inventory valuation: cost method). staffsite.gunadarma.ac.id/remi/index. php? stateid $=$ download $\& i d=8448 \& p$ art=files . Diakses tanggal $5 \mathrm{Mei}$ 2008.

[7]. Budi Santoso. 2007. Data Mining: Teknik Pemanfaatan Data Untuk Keperluan Bisnis. Yogyakarta: Graha Ilmu.

[8]. Bunafit Nugroho. 2008. Panduan Lengkap Menguasai Perintah SQL. Jakarta:Mediakita.

[9]. Handojo, Andreas. Satia Budhi, Gregarius, Rusly, Hendra. Aplikasi Data Mining Untuk Meneliti Asosiasi Pembelian I Tem Barang Di Supermaket Dengan Metode Market Basket Analysis. http://fportfolio.petra.ac.id/user_files 100 -

016/Data\%20Mining\%20Andreas\%2 OHandojo.pdf, Diakses tanggal 13 Juli 2008.

[10]. Holy Icun Yunarto dan Martinus Getty Santika. 2005. Bussines 
Concepts Implementation Series In Inventory Management. Jakarta: PT Elex Media Komputindo.

[11]. Husni. 2004. Membuat Aplikasi Database Client-Server Dengan Delphi Dan MySql. Graha Ilmu: Yogyakarta.

[12]. Kusrini. 2007. Konsep dan Aplikasi system Pendukung Keputusan. Yogyakarta: C.V Andi Offset.

[13]. Kusrini dan Emha Taufiq L. 2009. Algoritma Data Mining. Yogyakarta: C.V Andi Offset.

[14]. Liliana dan Denny Fransiskus. Sistem Inventory Dengan Menggunakan Metode Persediaan FIFO dan Average. fportfolio.petra.ac.id/user_files/03024/SistemDistribusi.doc. Diakses tanggal 13 Juli 2008.

[15]. Nofri Defri Anda. 2002. Data Mining Menggunakan Jaringan Saraf Tiruan Untuk Aplikasi Inventori. Surabaya: ITS.

[16]. Oka Sudana. 2008. Sistem Informasi Manajemen Inventori Pada Perusahaan Layanan Jasaboga Pesawat Udara .

[17]. Oemar Hamalik. 1993. Pengeleloaan Sistem Informasi. Bandung: Trigenda Karya.

[18]. Paulus, Andi Khrisbianto, dan Erwin Budi Setiawan. 2005. Sistem Informasi, Berbagai Makalah Tentang Sistem Informasi Dari Perspektif: Manusia Dan Sistem Informasi, Organisasi Dan Sistem Informasi, Teknologi Dan Sistem Informasi Yang Disampaikan Dalam Konferensi Nasional Sistem Informasi. Bandung: Informatika Bandung.

[19]. Richardus Eko Indrajit dan Richardus Djokopranoto. 2003. Manajemen Persediaan Barang
Umum Dan Suku Cadang Untuk Keperluan Pemeliharaan, Perbaikan, Dan Operasi. Jakarta: Penerbit PT Grasindo.

[20]. Rizky Dermawan. 2004. Sistem Informasi

Manajemen. Yogyakarta:Andi

[21]. Robi'in, Bambang. 2002. InterBase Menggunakan Delphi 6.0. Yogyokarta: Andi

[22]. ST Sujana, Asep. 2005. Paradigma Baru Dalam Manajemen Ritel Modern, Yogyakarta: Graha Ilmu.

[23]. Syaikh Shafiyyur Al-Mubarak. 2006. Tafsir Ibnu Katsir. Bogor: Pustaka Ibnu Katsir.

[24]. Tata Sutabri. 2005. Sistem Informasi Manajemen. Yogyakarta: Andi Offset.

[25]. Tedy Marcus, Agus Prijono, Josef Widiandhi. 2005. Pemograman Delphi Dengan AdoExpress. Bandung: Penerbit Informatika.

[26].

staffsite.gunadarma.ac.id/karami/inde x.php?stateid $=$ download $\&$ id $=4355 \&$ part=file. Diakses pada Tanggal 5 Mei 2008.

[27]. Dafferianto. 2009. Borland Interbase 7.1, ,2010.

www.dafferianto.web.ugm.ac.id/my study/.../Tugas\%20Interbase.doc. Diakses Tanggal 21 Oktober 2009.

[28].

2008 .

http://ejournal.unud.ac.id/?module= detailpenelitian $\& i d f=2 \& i d j=2 \& i d v=$ $110 \& i d i=98 \& i d r=548$. Diakses pada tanggal 13 Juli 2008.

[28]

greg@petra.ac.id. $\quad$ Diakses $\overline{\text { pada }}$ Tanggal 7 Juli 2008. 
[29]. _ 2009. Data Mining. http://haniif.wordpress.com/2007/05/ 07/data-mining/. Diakses pada tanggal 7 Mei 2009.

[30]. . 2008. Data Warehouse. http://www.iwayan.powernet.or.id/Le cture/DBaseLanjut_S1/M9\%20-

\%20DBMS.pdf. Diakses pada tanggal 8 Mei 2008.

[31].

http://ilmukomputer.com/2006/09/01

/membuat-data-model-untuk-datawarehouse/ (8 Mei 2008). http://sitiaits.net/data/data/papers/1.doc (12 Desember 2007).

[33]._2009.___ http://209.85.165.1 04/search?q=cache:i7jVIZ4rjGEJ:ge ocities.com/ineth_84/revisi+definisi+ sistem+informasi+koperasi+simpan+ pinjam $\& \mathrm{hl}=\mathrm{id} \& \mathrm{ct}=\mathrm{clnk} \& \mathrm{~cd}=3 \& \mathrm{gl}=\mathrm{i}$ d (30 Mei 2007). http://www.pdfqueen.com/html/aH R0cDovL3dzaWxmaS5zdGFmZi5n dW5hZGFybWEuYWMuaWQvRG 93bmxvYWRzL2ZpbGVzLzQ0MD kvT0xBUC5wZGY=, diakses pada tanggal 8 Maret 2010).

[34]. _. 2010. Desain Dan Implementasi Data Warehouse Penjualan Untuk Mendukung Sistem Manajemen Inventori Salah Satu Swalayan Di Surabaya, http.docstoc.com/docs/downloaddoc. aspx/? doc-id=20428492. Diakses Tanggal 10 Januari 2010. 